\title{
Anna Braisier
}

\author{
Big Water
}

W

e are all immigrants. The indigenous own the land and the rest of us, we came, borrowed, squatted.

I keep this in mind when I arrive in Sydney for a recent family holiday.

Day one of our stay we walk the few blocks from our city hotel to The Rocks, the once beating heart of the new colony-a place where people lived and businesses thrived in our fledgling nation. Today it is home to throngs of tourists.

When I look around at this settlement of sandstone walls and steps, I see ghosts from the past. I close my eyes and imagine what it may have been like before the cars, before the planes and the motorised boats. When I look out to the harbour most of the vista is blocked by a large cruise ship docked at the quay. The white sails of the Opera House peak through the foliage of the tall trees in Centennial Park and the Sydney Harbour Bridge looms heavy and dark on the left.

But back then there would've been trees, sand, stone.

European settlers arrived in 1788 and quickly established an open tent-city. In the years that followed The Rocks area developed into a thriving port and soon warehouses, pubs, stables, hospitals, brothels, and nurses' quarters were built using the abundant sandstone and local wood.

As the city expanded, it grew beyond this area and The Rocks eventually became a place where only the poor and lower classes dwelled. It was a dilapidated, neglected and forgotten site.

In the early 1970 s protesters fought against demolition and corporate expansion. 
Eventually a compromise was reached between developers and historians. Today The Rocks has been restored and invigorated by restaurants, artist shops, galleries, and craft markets. It has become a living museum on the edge of the city.

I can smell the history in the dank narrow laneways, in the old stables and in the dark attics. I imagine the dust, heat, flies and filth. I see rum swishing in barrels that would've been rolled off the ships and down wooden planks to musty cellars. I hear shouting from the dockyards as men worked to unload cargo that had travelled months to get here.

I imagine the cold, the sickness, the fear; the unknown of the new land. I have a new respect for our early settlers and I admire their strength. I feel indebted to these early fathers and mothers.

I lead my family on a walking tour. We walk along the back lanes, stopping every now and then to read the plaques on the walls. My hand lingers over the rough surface of the sandstone walls. The stone feels cool and rough.

We enter the history centre and walk up old wooden steps, shiny from years of wear. There is a sign on a cross-beam, telling people to mind the low ceiling; I take note and duck my head as I walk under the low hanging beam.

I run my hand across the worn boards; my fingers trace the lines and bumps of the aged wood. It reminds me of my father's hands. They too, were old and worn, bumped and scraped, through years of hard work. Dad was a builder. In Italy, during his teenage years, he worked on the shipyards of Piran, smoothing and shaping wooden boards; bending and contorting them into shape.

However, lifein post-war Italy was difficult and with poor employment prospects the future looked bleak. In 1956, my parents, along with their toddler, my older brother, sailed to Australia aboard La Toscana; a war-time troop ship which now carried post-war immigrants to a new land. My parents sought a new life in Australia which promised more than just wide skies and golden beaches.

It promised work and a future.

Growing up, I heard the story of their journey many times. It is my history. Like the early settlers back in 1788 , we too are foreigners to this land.

Indigenous history is displayed throughout the centre. I think back to those early settlement years and try to imagine how overwhelmed the 
Cadigal people, the indigenous owners of the land, must have felt. What did they make of it all when they saw the tall-ships arrive? The arrival of white settlers heralded the demise of their culture and as a result the indigenous community became a decimated and marginalised society.

A few days later we leave Sydney and drive south towards Victoria; we break our journey in Albury. I have planned to visit another place of historical significance, another open, living museum. Bonegilla Migrant Camp.

We cross the great Murray River into Victoria and head towards the Hume Weir. Near the shores of the lake is Bonegilla.

We turn off the main road onto a narrow gravel driveway which takes us to the camp's entrance. I feel my throat constrict when I see the faded white huts near the car park, familiar to me from old black and white snapshots. The huts remind me of old school portables.

It is a perfect spring day. Bright sunshine reflects off the huts' corrugated iron roofs which glare brilliantly against the blue sky, and native birds chatter in the bush. Our feet crunch on the gravel path as we walk towards the visitor centre.

My husband comments about how beautiful it is here.

“They were placed right in the country, weren't they?" he asks. I nod, not trusting myself to speak. I look about me and note the lush green grass. Thanks to a wet winter, spring is flourishing here. Devoid of people, it is a peaceful place with tall trees that sway slightly in the morning breeze.

Did my parents think Bonegilla was beautiful? They always spoke about their time spent at Bonegilla with affection. Although they acknowledged the camp's flaws, they were grateful for the chance they had been given, the chance to start again.

My parents arrived at the camp on a cold August night. After spending six weeks on-board ship in crowded cabins and surrounded by sea and sky, they travelled by train from Spencer Street Station to Bonegilla. As the train wove through the northern Melbourne suburbs and past desolate country towns on its way to Bonegilla, their excitement grew. Upon arrival they were assigned their own hut. My Dad always recalled with humour how they undressed in the dark for fear of tugging on the strange wire that hung from the ceiling, not realising until morning that it had been the light switch. "It was the happiest night of my life," he said. 
The woman at the visitor centre smiles at us and enquires whether we have any special connections to the camp. "My parents came here in 1956 from Italy," I manage to say before my emotions overcome me. I grab a pamphlet for a self-guided walking tour and turning towards my children, usher them back outside into the bright sunshine.

The memorial wall is our first point of interest. On one side of the wall a movie is playing. The large screen is filled with grainy images of people that came to Bonegilla. I stop and listen; their stories are familiar to me. These are the stories I heard in my childhood, depression, war, hunger. The rest of the wall is covered in tiny plaques; it reads like a roll-call of residents; surnames, towns, and countries. Each plaque with its own past.

Previously used as an army training camp, Bonegilla was well equipped to house migrants after the Second World War. The camp was like a small town, with all necessary amenities contained within its walls.

I read aloud from the pamphlet, "It had a hospital, police station, church, movie theatre, library, school, butcher." I stop reading and look at the handful of buildings that remain and try to imagine the once thriving migrant town.

We continue on with our walk. The next stop is the common wash room. It comprises a large washbasin and several showers.

"It's very old", remarks my son.

"Can you imagine Nonna coming here with your uncle as a baby to wash him?" I ask. The tour notes point out to visitors the long distance of the wash room in relation to the sleeping quarters. I think of the difficulty my mother would have faced.

We move on to the recreation hall. There is a fireplace at each end of this long room; our footsteps echo in the vast empty hall. A claymation movie is showing on a television at the far end of the room and my children sit down to watch it.

"That man talks like Nonno," my son remarks.

"He's complaining a lot."

The clay figure, with a cigarette dangling at the side of his mouth, recounts what life at Bonegilla was like, "the food was terrible. Can you imagine pasta with tomato sauce?"

"I remember Nonno telling me about that,"

I say. Life at the camp wasn't home, not yet. 
We continue our tour past the administration area. This section housed the employment services, and it is here where my Dad would have gone to get his worksheet stamped and signed when he worked at the Hume Weir.

Moving on to the sleeping huts, I note how sparsely furnished they are. This may be one of the reasons why almost all of the photos of the camp were taken outside.

As I walk from one building to another I don't linger inside for too long. The rooms smell stale and musty; I feel suffocated by the lack of air. Bonegilla was a place of hope and new life for so many, yet I can feel sadness here too.

I feel the loss of what they left behind, and in these cold, draft-filled rooms I feel their disappointment in the basic conditions, the bland food, and the lack of early employment prospects. Where was the golden future they were promised? I understood their loss; here in this place where everything was bare, harsh and sterile.

Welcome to Australia.

Eventually, many migrants found work on the Snowy River Scheme, and some, like my Dad, worked on the Hume Weir Dam.

Back outside I breathe in the fresh spring air and make my way to the last point of my tour. Tiny speakers are hidden within the wall; voices emanate from within. The effect is quite eerie as I find myself surrounded by ghosts of the past. Their voices are young, hopeful.

In Sydney, I stood in the heart of the nation's birthplace. Today, I stand in the place where my parents shaped their dreams, their Australian birthplace.

Here, in the land which the Wiradjuri people call Big Water, is where they let go of yesterday and pushed forward into tomorrow.

Before I leave I return to the visitor centre and flip to a blank page in the Guest Book. I write my name, date and address; and an inscription:

'In honour of my parents, who came to Australia to begin a new life'

My husband and I follow the children, who have run ahead of us to the car. They are eager to be on the move again. They are too young to understand the significance of the threads of the past. The need I feel to connect with what has come before me. One day, they may come back here again and say, "This is where our family's journey in Australia began.” 